British \& Irish Botany 1(3): 219-230, 2019

\title{
Pangium edule (Achariaceae) drift endocarps: first records from Britain and Bermuda and a review of NW European records
}

\author{
Declan T.G. Quigley ${ }^{1, *}$; Paul A. Gainey ${ }^{2}$; Andy Dinsdale ${ }^{3}$ \\ ${ }^{1}$ Dingle, Co Kerry, Ireland; ${ }^{2}$ Penryn, Cornwall, UK; ${ }^{3}$ Fairlight, East Sussex, UK.
}

*Corresponding author: Declan T.G. Quigley: declanquigley@eircom.net

This pdf constitutes the Version of Record published on $13^{\text {th }}$ August 2019

\begin{abstract}
During 2015, two drift endocarps of Pangium edule were found stranded in southern British waters, the first from Dungeness, Kent (25/09/2015) and the second from Loe Bay Beach, Cornwall (13/11/2015). The specimens represent the first records of $P$. edule drift endocarps from British waters. Four specimens have previously been recorded from Dutch (3) and Danish (1) waters. A first record of $P$. edule from Bermuda (NW Atlantic) in mid-December 2015 is also reported.
\end{abstract}

Keywords: seed dispersal; buoyancy; ocean currents; ethnobotany

\section{Introduction}

Pangium edule Reinwardt (Achariaceae) is considered to be a monotypic species but its taxonomic position is currently uncertain (Chase et al., 2002; Rana \& Ranade, 2009; Wurdack \& Davis, 2009). P. edule is native to Malesia (Indonesia, Malaysia, Philippines), Melanesia (Papua New Guinea, Fiji), and Micronesia (Hemsley, 1885; Merrill, 1918; Bourke, 1996; Walter \& Sam, 1996; Costion \& Lorence, 2012). Although the species has a localised distribution in the clayey foothill region of Laful Forest, Great Nicobar Island, in the eastern Indian Ocean (Hore et al., 1985), it does not occur in mainland India (Chakrabarty pers. comm.). P. edule was deliberately introduced into Australia during 1972 by the Common Wealth Introduction Service (Randall, 2007).

$P$. edule is a tall tree reaching up to $45 \mathrm{~m}$ in height commonly found in coastal and lowland interior forests along river banks (Ridley, 1930; Smith, 1999; Anon, 2014). The tree produces large (16-24 by $12-16 \mathrm{~cm})$ green pendulous 'footballshaped' cylindric-globose fruits, each containing 13-40 hard stony, reticulated, ribbed, triangular-ovoid seeds (3.5-6.0 cm), embedded in a pungent mesocarp (Van Heel, 1974; Hore et al., 1985; Faridah-Hanum, 1996). Each seed has a conspicuously prominent (3-6 cm long, and up to $1.5 \mathrm{~cm}$ wide) 'lip-like' hilum (Gunn \& Dennis, 1999; Nelson, 2000; Perry \& Dennis, 2010). Some seeds inevitably find their way into rivers and eventually float out to sea where they are widely dispersed by oceanic currents.

Although the fruits and seeds of $P$. edule contain poisonous cyanogenic glycosides (Vetter, 2000), they form part of the natural diet of Babyrousa babyrussa (L.), a wild pig native to the Togean Islands, Sulawesi, Indonesia (Akbar et al., 2007). Nevertheless, following boiling, roasting and/or fermentation, the onion- 
flavoured fruits and seeds of both wild and cultivated $P$. edule are widely used in the preparation of various culinary dishes and as a food preservative throughout southeast Asia (Hore et al., 1985; Bourke, 1996; Faridah-Hanum, 1996; Walter \& Sam, 1996; Smith, 1999; Chakrabarty \& Balarkishnan, 2003; Blench, 2004; Salma et al., 2006; Kasim \& David, 2013).

The seeds and bark of $P$. edule are also used for various medicinal purposes and as a fish poison by some native tribes in the Asia-Pacific region (Sharief \& Rao, 2007; Hariyadi \& Ticktin, 2012; Lim, 2013; Rai, 2013). The seeds contain large amounts of oil which is used for cooking, as an electrolyte, in the manufacture of soap and fuel for lamps, and as a potential source of biodiesel (Cadée, 1988; Nelson, 2000; Nofiarli \& Nurdin, 2013). Smith (1999) and Hopkins (2000) noted that hollow seeds are used in making handicrafts, such as necklaces and wind chimes. A number of musical instruments originating from Indonesia and New Guinea housed in the ethnobotanical collections of Kew Gardens (London) utilized hollow $P$. edule seeds as 'shakers' (Catalogue Nos: 97873-75) and as a decoration on a drum (Catalogue No. 66999).

\section{NW European \& Bermuda records of Pangium edule}

On 25 September 2015, AD discovered a drift endocarp of $P$. edule stranded at Dungeness (TR006177; $\left.50.9193^{\circ} \mathrm{N}, 0.9653^{\circ} \mathrm{E}\right)$, Kent (Fig. 1). The maximum dimensions of the endocarp were $43 \mathrm{~mm}$ wide, $23 \mathrm{~mm}$ deep, and the hilum length was $39 \mathrm{~mm}$. The remains of mesocarp pulp were still adhering to the endocarp.

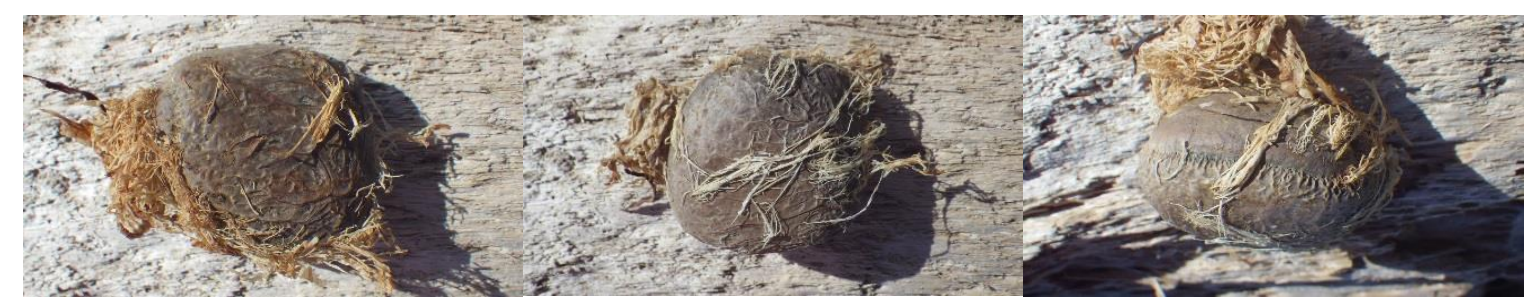

Figure 1. Drift endocarp of Pangium edule from Kent, September 2015

On 13 November 2015, a second $P$. edule drift endocarp was discovered by PAG stranded on Loe Bar Beach (SW643242; 50.07 $\left.\mathrm{N}, 5.2945^{\circ} \mathrm{W}\right)$, near Helston, Lizard, Cornwall (Fig. 2). The maximum dimensions of the endocarp were $42 \mathrm{~mm}$ wide, $28 \mathrm{~mm}$ deep, and the hilum length was $39 \mathrm{~mm}$. There were no remains of any mesocarp pulp adhering to the endocarp. The current specimens represent the first records of $P$. edule drift endocarps from British waters.

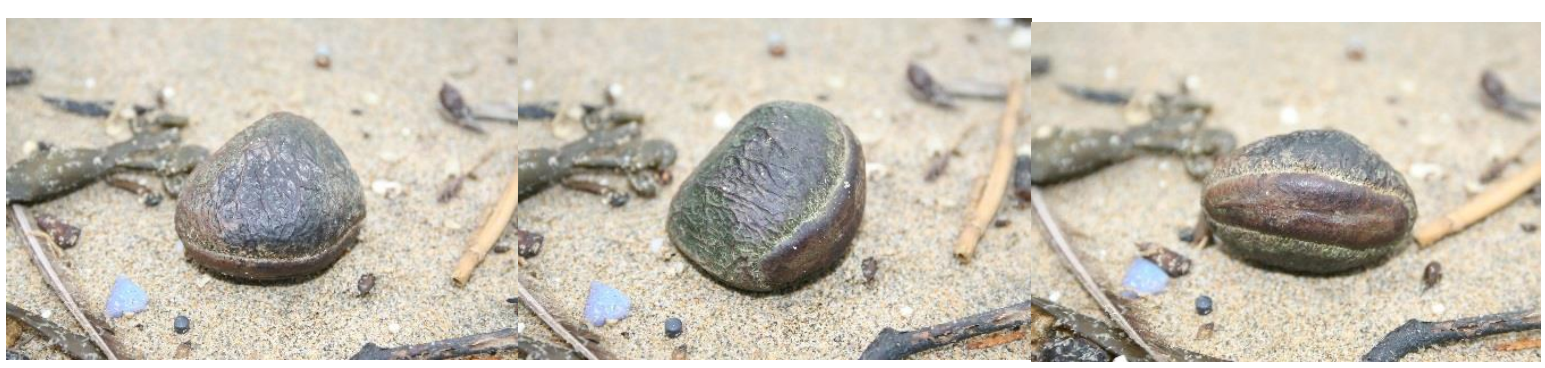

Figure 2. Drift endocarp of Pangium edule from Cornwall, November 2015 
Details of all known NW European records of $P$. edule drift endocarps are summarised in Table 1. Since 1971, a total of six specimens have been recorded, including three from the Dutch coast, one from Denmark, and two from Britain.

Table 1. North-West European records of Pangium edule drift endocarps

\begin{tabular}{|c|c|c|c|c|}
\hline Date & Location & $\begin{array}{l}\text { Coordinate } \\
s\end{array}$ & Collector & Refs. \\
\hline $13 / 07 / 1971$ & $\begin{array}{l}\text { Shouwen, } \\
\text { Burghsluis, } \\
\text { Netherlands }\end{array}$ & $\begin{array}{l}51.6750^{\circ} \mathrm{N} \\
3.7526^{\circ} \mathrm{E}\end{array}$ & $\begin{array}{l}\text { J. } \\
\text { Viergever }\end{array}$ & Cadée (1986) \\
\hline 1974 & $\begin{array}{l}\text { Ho Bugt, } \\
\text { near } \\
\text { Esbjerg, } \\
\text { Denmark }\end{array}$ & $\begin{array}{l}55.4703^{\circ} \mathrm{N} \\
8.4518^{\circ} \mathrm{E}\end{array}$ & $\begin{array}{l}\text { Bertil } \\
\text { Hansen }\end{array}$ & Nelson (2000) \\
\hline $03 / 06 / 1992$ & $\begin{array}{l}\text { Texel, } \\
\text { Netherlands }\end{array}$ & $\begin{array}{l}53.0548^{\circ} \mathrm{N} \\
4.7977^{\circ} \mathrm{E}\end{array}$ & $\begin{array}{l}\text { G. } \\
\text { Frederiks }\end{array}$ & Cadée (1995) \\
\hline 2004 & $\begin{array}{l}\text { Terschelling, } \\
\text { Netherlands }\end{array}$ & $\begin{array}{l}53.3979^{\circ} \mathrm{N} \\
5.3467^{\circ} \mathrm{E}\end{array}$ & $\begin{array}{l}\text { G.H. } \\
\text { Feenstra } \\
\text { G. } \\
\text { Doeksen }\end{array}$ & $\begin{array}{l}\text { Brochard \& } \\
\text { Cadée (2005) }\end{array}$ \\
\hline $25 / 09 / 2015$ & $\begin{array}{l}\text { Dungeness } \\
\text { (TR006177), } \\
\text { Kent, UK }\end{array}$ & $\begin{array}{l}50.9193^{\circ} \mathrm{N} \\
0.9653^{\circ} \mathrm{E}\end{array}$ & $\begin{array}{l}\text { Andy } \\
\text { Dinsdale }\end{array}$ & This paper \\
\hline $13 / 11 / 2015$ & $\begin{array}{l}\text { Loe Bar } \\
\text { Beach } \\
\text { (SW643242) } \\
\text {, near } \\
\text { Helston, } \\
\text { Cornwall, } \\
\text { UK }\end{array}$ & $\begin{array}{l}50.0700^{\circ} \mathrm{N} \\
5.2945^{\circ} \mathrm{W}\end{array}$ & $\begin{array}{l}\text { Paul A. } \\
\text { Gainey }\end{array}$ & This paper \\
\hline
\end{tabular}

During mid-December 2015, a specimen of $P$. edule measuring $41 \mathrm{~mm}$ in length, $38 \mathrm{~mm}$ in width and $21 \mathrm{~mm}$ in depth, was discovered by Roger "Grassy" Simmons on Natural Arches Beach, St. George's, Bermuda $\left(32.3328^{\circ} \mathrm{N}, 64.6881^{\circ} \mathrm{W}\right)$, NW Atlantic (BAMZ 2016296 006, Liza Green, pers. comm.). There were no remains of any mesocarp pulp adhering to the endocarp. The specimen (Fig. 3) represents the first record of a $P$. edule drift endocarp from Bermuda. 


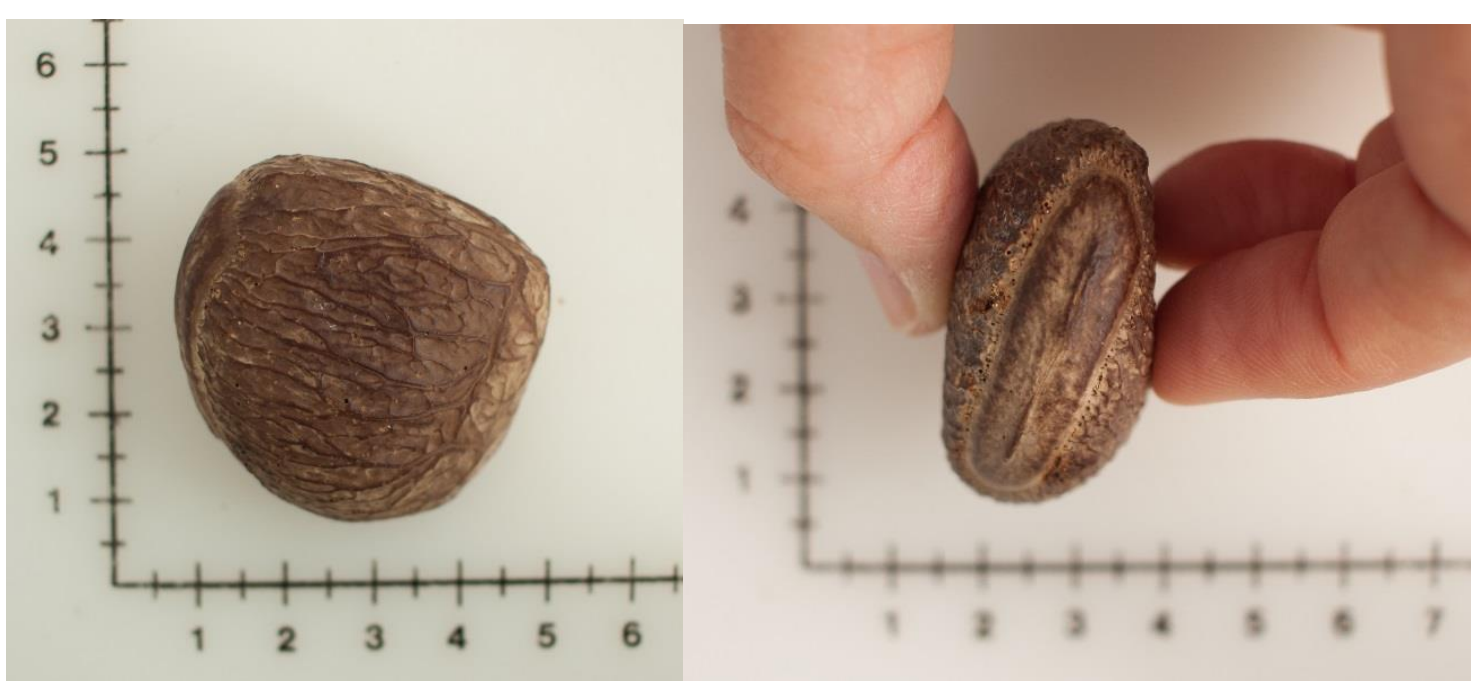

Figure 3. Drift endocarp of Pangium edule from Bermuda, December 2015

There was no evidence of marine bio-fouling epibionts on the external surface of either the NW European or Bermuda endocarps of $P$. edule. The presence of epibionts would suggest that the endocarps had been drifting for a significant period of time at sea prior to stranding. However, it is possible that cyanogenic toxins within $P$. edule endocarps may inhibit the growth of potential epibionts. It is interesting to note that all three specimens were discovered during the autumn and winter of 2015.

\section{Discussion}

Nelson (2000) and Thiel \& Gutow (2005) stated that $P$. edule seeds are capable of floating for at least 19 years, whereas Perry \& Dennis (2010) remarked that they can float for 30 years. Van Heel (1974) noted that the seeds appear to be hollow and that this possibly accounts for their floating capacity. Ridley (1930) remarked that although the seeds can float easily for a long time, they do not survive the action of sea water, and never seem to have reached any oceanic island alive. Gunn \& Dennis (1999) noted that while the intact seed coat provides excellent buoyancy and may drift for great distances, the embryo in these drift seeds is usually absent or nearly so. In Australia, Smith (1999) noted that stranded seeds are usually hollow although sometimes still containing a malodorous rotting kernel.

Gunn \& Dennis (1999) noted that when fresh $P$. edule seeds are freed from the decaying fruit, they are covered with a white fleshy aril which is soon eroded. It is interesting to note that the remains of mesocarp pulp were still adhering to the Dungeness endocarp which strongly suggests that the specimen was recently discarded. Many NW European cities are home to large ethnic populations with an ancestral knowledge of the poisonous, medicinal and culinary properties of $P$. edule, and unknown quantities may be imported into Europe either for commercial and/or personal use, and some may be locally discarded. Indeed, $P$. edule seeds are currently marketed internationally on various websites.

Drift endocarps of $P$. edule have been recorded from a wide geographical area within the Indo-Asian-Pacific region, including the Cocos-Keeling Islands (Guppy, 1890) and Christmas Island (Ridley, 1930; Green, 1999) [eastern Indian Ocean], Australia (Kenneally, 1972; Hacker, 1990; Smith, 1994, 1999; Smith et al., 1990; 
Pike \& Leach, 1997), Malaysia (Ridley, 1930), Java (Ridley, 1930), Taiwan (Anon, 2016), and Japan (Longhorn, 2004; Nakanishi, 2011). However, despite their known long-term floatation capacity, there are no confirmed strandings from either the central or eastern Pacific Ocean (Flynn \& Van der Burgt, pers. comm.), western Indian Ocean, including SE Africa (Muir, 1937; Hosten-Willems, 2005; Burrows, pers. comm.), South Atlantic Ocean, including NW Africa (Van der Burgt, 1997, 1998), and only rarely from the NW and NE Atlantic Ocean (Gunn \& Dennis, 1999; Perry \& Dennis, 2010; this paper).

In the NW Atlantic, Perry \& Dennis (2010) noted that there were no records of $P$. edule drift endocarps from Yucatan, Gulf Coast or Carolina shores, and that the seeds are a rarity on the east coast beaches of Florida. Indeed, Perry (pers. comm.) remarked that he was only aware of two definitive records of $P$. edule drift endocarps from the NW Atlantic, both from Melbourne Beach, Florida $\left(28.0683^{\circ} \mathrm{N}\right.$, $80.5603^{\circ} \mathrm{W}$ ), one during the 1970 s, and another during the $1990 \mathrm{~s}$.

It has frequently been suggested that the endocarps of $P$. edule found stranded on NW European coasts were unlikely to be true peregrine drifters, and were most likely transported and discarded there by man on the basis that no ocean current could be envisaged that transports seeds from the Indo-Asian-Pacific region to NW Europe (Cadée, 1986, 1988, 1995, 1997; Nelson, 2000; Cadée \& Nijhuis, 2001; Brochard \& Cadée, 2005). Although the rarity of stranded $P$. edule specimens in the North Atlantic Ocean and the absence of records from the South Atlantic and western Indian Ocean lend support this hypothesis, it is conceivable that some endocarps may have drifted from the Indo-Asian-Pacific region.

Gunn \& Dennis (1999) noted that the Malayan region (including Indonesia) is a major epicentre for drift disseminules. Currents passing this region carry disseminules both eastwards into the Pacific and westwards across the Indian Ocean. Although the continent of Africa effectively blocks most movement westwards beyond the Indian Ocean, a few species have successfully rounded the Cape of Good Hope via the Agulhas Current into the Atlantic and have achieved a pantropical distribution (Steinke \& Ward, 2003; Schaefer et al., 2009; Michalak et al., 2010; Thomas et al., 2015).

Several oceanographical studies have demonstrated that Indian Ocean water frequently leaks via the Agulhas Current around the southern tip of South Africa into the South Atlantic and is carried northwards along the western coast of Africa via the Benguela Current and westwards via the South Atlantic Drift to South America (Garzoli et al., 1999; Boebel et al., 2003; Steinke \& Ward, 2003; Richardson et al., 2003; Richardson, 2007; Van Sebille et al., 2009; Dencaussea et al., 2010; Guerra et al., 2018), and possibly thence via the Gulf Stream and North Atlantic Drift to NW Europe. Ebbesmeyer (2003) noted that a plastic drift card which had been released off Cape Town on 17 April 1966 was recovered 19 months later on 25 September 1968, at Stuart Beach, $80 \mathrm{~km}$ north of Miami, SE Florida, USA, having drifted at an average speed of c. $14 \mathrm{~km} /$ day. He also noted that a large log of mahogany originating from a wreck in the Mozambique Channel, between the eastern coast of Africa and Madagascar (Indian Ocean), was found stranded at Cape Town, on the Atlantic coast of South Africa, and hypothesized that some of these mahogany logs could wash ashore in Britain if they remained afloat for 4 years.

Nathan (2006) recognised that long-distance dispersal (LDD) of plants poses challenges to research because it involves rare events driven by complex and highly 
stochastic processes. He suggested that nonstandard mechanisms such as extreme climatic events and generalized LDD vectors seem to hold the greatest explanatory power for the drastic deviations from the mean trend, deviations that make the nearly impossible LDD a reality. Smith et al. (2018) acknowledged that although LDD dispersal events occur rarely, they play a fundamental role in shaping species biogeography. Indeed, they discovered that the Australian Grass-Wrack Heterozostera nigricaulis J. Kou had naturally dispersed across the entire Pacific (c. $14,000 \mathrm{~km}$ ) to colonize coastal areas in Chile (South America).

Renner (2004) hypothesized that trans-Atlantic dispersal of diaspores by water probably accounted for the occurrence of at least 110 genera of plants which contain species on both sides of the tropical Atlantic (Africa and South America). Kistler et al. (2014) hypothesized that trans-Atlantic drift most likely accounted for the successful establishment of wild African Bottle Gourds Lagenaria siceraria (Molina) Standley in neo-tropical areas of the New World during the late Pleistocene. During 1998, viable propagules of the Indo-Malaysian Mangrove Palm Nypa fruticans Wurmb were discovered on the coast of Trinidad in the Caribbean Sea (Bacon, 2001). The propagules were thought to have drifted across the Atlantic from naturalized populations in West Africa where the species was introduced during the early $20^{\text {th }}$ century (Sunderland \& Morakinyo, 2002). Although specimens have occasionally been recorded from NW Europe, they are generally considered to have been imported and locally discarded (Nelson, 2000; Brochard \& Cadée, 2005). However, considering the of $N$. fruticans occurrence in the Caribbean region, it is conceivable that the NW European specimens could have originated in West Africa.

A number of other disseminules of Indo-Asian-Pacific origin have been recorded, albeit rarely, from NW European waters (Nelson, 2000), including Attalea funifera Martius (Cadée, 1988), Heritiera littoralis Aiton (Cadée, 2001), and Cerbera $s p$. (Quigley \& Fenwick, in press), but they are generally thought to have been imported and locally discarded rather than true peregrine drifters.

Although vast numbers of disseminules are passively dispersed by ocean currents, only a fraction of these remain buoyant, intact and potentially viable; most undoubtedly either sink, disintegrate or are stranded undetected in inhospitable areas where there can be no expectation of establishment. It is possible that $P$. edule drift endocarps and other Indo-Asian-Pacific disseminules may occur more frequently in NW European waters than the current paucity of records would suggest; their apparent rarity may simply reflect a lack of recording effort throughout most of the Atlantic region. Although it is likely that the occurrence of $P$. edule drift endocarps in NW European waters may be due to local discarding, it is also conceivable, considering their long-term buoyancy (up to 30 years), that some may have passively drifted here from the Indo-Asian Pacific region.

\section{Acknowledgements}

We are grateful to the following for their assistance: Gerhard Cadée (Koninklijk NIOZ, den Burg, Netherlands), Xander van der Burgt (Royal Botanic Gardens, Kew, London, UK), John and Sandie Burrows (Buffelskoof Nature Reserve and Herbarium, Lydenburg, Mpumalanga, South Africa), Tim Flynn (National Tropical Botanical Garden, Kalaheo, Hawaii, USA), Liliane Hosten-Willems \& Eric Hosten (Port Elizabeth, South Africa), Ed Perry (Melbourne Beach, Florida, USA), Tapas Chakrabarty (Botanical Survey of India, Kolkata, West Bengal, India), Rod Randall (Department of 
Agriculture and Food, South Perth, Western Australia), Philip Richardson (Physical Oceanography Department, Woods Hole Oceanographic Institution, Massachusetts, USA), and Lisa Green (Bermuda Museum of Natural History).

\section{References}

Akbar, S., Indrawan, M., Yasin, M.P., Burton, J. \& Ivan, J. 2007. Status and conservation of Babyrousa babyrussa in the Togean Islands, based on direct observations and questionnaire surveys (intermittently, 1990-2001). Suiform Soundings (PPHSG Newsletter), 7(1): 16-25. http://repo.unand.ac.id/4239/1/JRN-R-03.pdf

Anon, 2014. Pangium edule. In: eFlora of India. Botanical Survey of India. [Accessed 27 August 2018]. http://efloraindia.nic.in/efloraindia/taxonList.action?id=6525\&type $=4$

Anon, 2016. Studies on the flora of Pratas Is/and. Marine National Park Headquarters, Taiwan. https://www.marine.gov.tw/ecology-andconservation/research-report/258-2015/1949Studies\%20on\%20the\%20Flora\%200f\%20Pratas\%20Island

Bacon, P.R. 2001. Germination of Nypa fruticans in Trinidad. Palms, 45(2): 57-61. http://www.palms.org/palmsjournal/2001/vol45n2p57-61.pdf

Blench, R. 2004. Fruits and arboriculture in the Indo-Pacific region. Indo-Pacific Prehistory Association Bulletin (Taipei Papers 2), 24: 31-50. https://journals.lib.washington.edu/index.php/BIPPA/article/view/11869/10496

Boebel, O., Duncombe Rae, C., Garzoli, S., Lutjeharms, J., Richardson, P., Rossby, T., Schmid, C. \& Zenk, W. 1998. Float experiment studies interocean exchanges at the tip of Africa. Eos, Transactions American Geophysical Union, 79(1): 1-8. https://doi.org/10.1029/98EO00001

Boebel, O., Lutjeharms, J., Schmid, C., Zenk, W., Rossby, T. \& Barron, C. 2003. The Cape Cauldron: a regime of turbulent inter-ocean exchange. Deep-Sea Research Part II: Topical Studies in Oceanography, 50(1): 57-86. https://doi.org/10.1016/S0967-0645(02)00379-X

Bourke, R. 1996. Edible indigenous nuts in Papua New Guinea. In: Evans, M.L., Bourke, R.M. \& Evans, B.R., eds. South Pacific Indigenous Nuts, 45-55. Proceedings of a Workshop held from 31 October to 4 November 1994 at Le Lagon Resort, Port Vila, Vanuatu. ACIAR Proceedings No. 69.

Brochard, C.J.E. \& Cadée, G.C. 2005. Tropische drijfzanden van de Nederlandse kust. Tabellenserie van de Strandwerkgemeenschap 30: 1-66. http://www.vliz.be/imisdocs/publications/256608.pdf

Cadée, G.C. 1986. Een tropisch drijfzaad, Pangium edule Reinwardt (Flacourtiaceae), van het Nederlandse strand. Gorteria - Dutch Botanical Archives, 13(2): 44-45. http://www.repository.naturalis.nl/record/527917

Cadée, G.C. 1988. Attalea funifera Mart., and a review of other tropical seeds from the Dutch coast. Porcupine Newsletter, 4(3): 51-54, 59. http://pmnhs.co.uk/wp-content/uploads/2011/11/033-PNV4N30CT88.pdf

Cadée, G.C. 1995. Spoelen op Texel meer tropische zaden aan dan elders in Netherland? Nieuwe vondsten. Het Zeepaard, 55(1): 7-16.

Cadée, G.C. 1997. Tropical drift disseminules from the coast of the Netherlands: the human factor (continued). The Drifting Seed, 3(2): 3-4.

http://www.seabean.com/newsletters/vol03-2.pdf 
Cadée, G.C. \& Nijhuis, H. 2001. Heritiera littoralis, new for the Netherlands and Europe. The Drifting Seed, 7(1): 9-10. http://www.seabean.com/newsletters/vol07-1.pdf

Chakrabarty, T. \& Balarkishnan, N.P. 2003. Ethnobotany of the Andaman and Nicobar Islands, India - a review. Journal of Economic Taxonomic Botany, 27(4): 869-893.

Chase, M.W., Zmarzty, S., Lledo, M.D., Wurdack, K.J., Swensen, S.M. \& Fay, M.F. 2002. When in doubt, put it in Flacourtiaceae: a molecular phylogenetic analysis based on plastid $r b c$ DNA sequences. Kew Bulletin, 57(1): 141-181. https://doi.org/10.2307/4110825

Costion, C.M. \& Lorence, D.H. 2012. The endemic plants of Micronesia: a geographical checklist and commentary. Micronesica, 43(1): 51-100. https://www.researchgate.net/publication/269055933 The Endemic Plants of Micronesia A Geographical Checklist and Commentary

Dencaussea, G., Arhan, M. \& Speich, S. 2010. Routes of Agulhas rings in the southeastern Cape Basin. Deep Sea Research Part 1: Oceanographic Research Papers, 57(11): 1406-1421. http://dx.doi.org/10.1016/j.dsr.2010.07.008

Ebbesmeyer, C. 2003. Fun-stuff from Curt: $\$ 4,000$ African logs due in Florida. The Drifting Seed, 9(2): 2-5. http://www.seabean.com/newsletters/vol09-2.pdf

Faridah-Hanum, I. 1996. Morphological variation of Pangium edule Reinw. fruits in Malaysia. The Gardens' Bulletin Singapore, 48(1-2): 189-194. https://www.nparks.gov.sg/sbg/research/publications/gardens-bulletinsingapore/-/media/sbg/gardens-bulletin/4-4-48-1-2-07-y1996-v48-p1-p2-gbspg-189.pdf

Garzoli, S.L., Richardson, P.L., Duncombe Rae, C.M., Fratantoni, D.M., Goni, G.J. \& Roubicek, A.J. 1999. Three Agulhas rings observed during the Benguela Current experiment. Journal of Geophysical Research: Oceans, 104(C9): 2097120985. https://doi.org/10.1029/1999JC900060

Green, P.T. 1999. Greta's Garbo: stranded seeds and fruits from Greta Beach, Christmas Island, Indian Ocean. Journal of Biogeography, 26(5): 937-946. https://doi.org/10.1046/j.1365-2699.1999.00351.x

Guerra, L.A.A., Paiva, A.M., Chassignet, E.P. 2018. On the translation of Agulhas rings to the western South Atlantic Ocean. Deep-Sea Research Part:

Oceanographic Research Papers, 139: 104-113. https://doi.org/10.1016/j.dsr.2018.08.005

Gunn, C.R. \& Dennis, J.V. 1999. World guide to tropical drift seeds and fruits. New York: Demeter Press. Malabar, Florida: Krieger Publishing Co.

Guppy, H.B. 1890. On the dispersal of plants as illustrated by the flora of the Keeling or Cocos Islands. Journal of the Transactions of the Victoria Institute or the Philosophical Society of Great Britain, 24: 267-306. https://www.biodiversitylibrary.org/item/88180\#page/9/mode/1up

Hacker, J.B. 1990. Drift seeds and fruit on Raine Island, northern Great Barrier Reef, Australia. Journal of Biogeography, 17(1): 19-24. http://doi.org/10.2307/2845184

Hariyadi, B. \& Ticktin, T. 2012. Uras: medicinal and ritual plants of Serampas, Jambi Indonesia. Ethnobotany Research \& Applications, 10: 133-149. www.ethnobotanyjournal.org/vol10/i1547-3465-10-133.pdf 
Hemsley, E.B. 1885. Report on the Scientific Results of the Voyage of H.M.S. Challenger during the years 1873-76. Botany 1, Part 4. Report on the Botany of Juan Fernandez, the South-Eastern Moluccas, and the Admiralty Islands. London: Her Majesty's Stationery Office.

Hore, D.K., Vasudeva Rao, M.K. \& Chakrabarty, T. 1985. Pangium (Flacourtiaceae) a new generic record for India. Journal of Economic and Taxonomic Botany, 6(2): 417. https://www.researchgate.net/profile/Tapas Chakrabarty/publication/28657997 7 Pangium Flacourtiaceae a new generic record for India/links/566beb7308aea0892c4f409f/PangiumFlacourtiaceae-a-new-generic-record-for-India.pdf

Hosten-Willems, L. 2005. Beachcombing in Port Elizabeth - South Africa. The Drifting Seed, 11(1): 5-9. http://www.seabean.com/newsletters/vol11-1.pdf

Kasim, A. \& David, W. 2013. Characteristics of Pangium edule Reinw. as food preservative from different geographic sites. Asia Pacific Journal of Sustainable Agriculture and Energy, 1(1): 6-9.

https://www.researchgate.net/publication/258052966 Characteristic of Pangiu m Edule Reinw as food preservative from different geographical sites

Kenneally, K.M. 1972. Tropical seeds and fruits washed up on the south-west coast of Western Australia. The Western Australian Naturalist, 12(4): 73-80.

Kistler, L., Montenegro, A., Smith, B.D., Gifford, J.A., Green, R.E., Newsom, L.A. \& Shapiro, B. 2014. Transoceanic drift and the domestication of African bottle gourds in the Americas. Proceedings of the National Academy of Sciences of the USA (PNAS), 111(8): 2937-2941. www.pnas.org/cgi/doi/10.1073/pnas.1318678111

Lim, T.K. 2013. Pangium edule. In: Lim, T.K., ed. Edible Medicinal and Non-Medicinal Plants 5: 780-784. Springer Netherlands.

Longhorn, E. 2004. Typhoons make 2004 a bumper year for sea-beans in Japan. The Drifting Seed, 10(3): 10. http://www.seabean.com/newsletters/vol10-3.pdf

Merrill, E.D. 1918. Species Blancoanae: a critical revision of the Philippine species of plants described by Blanco and by Llanos. Department of Agriculture and Natural Resources Bureau of Science, Manilla No. 12. https://www.biodiversitylibrary.org/bibliography/2116\#/summary

Michalak, I., Zhang, L-B. \& Renner, S.S. 2010. Trans-Atlantic, trans-Pacific and trans-Indian Ocean dispersal in the small Gondwanan Laurales family Herandiaceae. Journal of Biogeography, 37: 1214-1226. http://doi.org/10.1111/j.1365-2699.2010.02306.x

Muir, J. 1937. The seed-drift of South Africa and some influences of ocean currents on the strand vegetation. Botanical Survey Memoir No. 16. Department of Agriculture and Forestry, Union of South Africa.

Nakanishi, H. 2011. Tropical drift fruits and seeds rarely found or newly found on the Japanese coast. Journal of the Japanese Driftological Society, 9: 1-5. http://drift-japan.net/wp/wp-content/uploads/2013/01/JDS9 20111 5.pdf

Nathan, R. 2006. Long-distance dispersal of plants. Science, 313(5788): 786-788. http://doi.org/10.1126/science.1124975

Nelson, E.C. 2000. Sea Beans and Nickar Nuts. A handbook of exotic seeds and fruits stranded on beaches in north-western Europe. BSBI Handbook No. 10. London: Botanical Society of the British Isles. 
Nofiarli, A.K. \& Nurdin, H. 2013. The biodiesel characteristics of Kepayang oil (Pangium edule Reinw.). ARPN Journal of Agriculture and Biological Science, 8(3): 241-244. http://www.arpnjournals.com/jabs/research papers/rp 2013/jabs 0313 544.p $\underline{\mathrm{df}}$

Perry, E. \& Dennis, J.V. 2010. Sea-Beans from the tropics: a collector's guide to seabeans and other tropical drift on Atlantic shores. Malabar, Florida: Krieger Publishing Company.

Pike, G.D. \& Leach, G.J. 1997. Handbook of the vascular Plants of Ashmore and Cartier Islands. Parks and Wildlife Commission of the Northern Territories/Parks, Darwin, Australia.

Quigley, D.T.G, \& Fenwick, D. in press. Cerbera sp. (Apocynaceae) drift mesocarps: first record from British waters and a summary of previous records from northwestern Europe. Cahiers de Biologie Marine, 60(5)

Rai, P.P. 2013. Country status report on medicinal and aromatic plants in Papua New Guinea. In: Paroda, R., Dasgupta, S., Mai, B., Ghosh, S.P. \& Pareek, S.K., eds. Proceeding of the Expert Consultation on Promotion of Medicinal and Aromatic Plants in the Asia-Pacific Region, 186-200. Bangkok, Thailand, 2-3 December 2013. https://www.gfar.net/sites/default/files/medicinal and aromatic plantsproceedings.pdf

Rana, T.S. \& Ranade, S.A. 2009. The enigma of monotypic taxa and their taxonomic implications. Current Science, 96(2): 219-229.

Randall, R.P. 2007. The introduced flora of Australia and its weed status. CRS for Australian Weed Management, Department of Agriculture and Food, Western Australia. https://www.une.edu.au/ data/assets/pdf file/0019/52372/2007.The-introduced-flora-of-Australia-and-its-weed-status.pdf

Renner, S. 2004. Plant dispersal across the tropical Atlantic by wind and sea currents. International Journal of Plant Sciences, 165(S4): 523-533. https://www.journals.uchicago.edu/doi/full/10.1086/383334

Richardson, P.L. 2007. Agulhas leakage into the Atlantic estimated with subsurface floats and surface drifters. Deep Sea Research Part i: Oceanographic Research Papers, 54: 1361-1389. https://doi.org/10.1016/j.dsr.2007.04.010

Richardson, P.L., Lutjeharms, J.R.E. \& Boebel, O. 2003. Introduction to the "Interocean exchange around southern Africa". Deep-Sea Research Part II: Topical Studies in Oceanography, 50(1): 1-12. https://doi.org/10.1016/S09670645(02)00376-4

Ridley, H.N. 1930. Dispersal of plants throughout the world. Reeve, London.

Salma, I., Mohd, A., Masrom, H. \& Raziah, M.L. 2006. Diversity and use of traditional fruit species in selected home gardens or fruit orchards in Malaysia. Journal of Tropical Agriculture and Food Science, 34(1): 149-164. http://ejtafs.mardi.gov.my/jtafs/341/Diversity\%20and\%20Use\%20of\%20Traditional\%20Fruit\%20Species.pdf

Schaefer, H., Heibl, C. \& Renner, S.S. 2009. Gourds afloat: a dated phylogeny reveals an Asian origin of the gourd family (Cucurbitaceae) and numerous oversea dispersal events. Proceedings of the Royal Society, 276B: 843-851. https://doi.org/10.1098/rspb.2008.1447 
Sharief, M.U. \& Rao, R.R. 2007. Ethnobotanical studies of Shompens - a critically endangered and degenerating ethnic community in Great Nicobar Island. Current Science, 93(11): 1623-1628.

Smith, J. 1999. Australian Driftseeds: A compendium of seeds and fruits commonly found on Australian beaches. School of Human and Environmental Studies, University of New England, Armidale, New South Wales, Australia.

Smith, J.M.B. 1994. Patterns of disseminule dispersal by drift in the north-west Coral Sea. New Zealand Journal of Botany, 32: 453-461. http://dx.doi.org/10.1080/0028825X.1994.10412932

Smith, J.M.B., Heatwole, H., Jones, M. \& Waterhouse, B.M. 1990. Drift disseminules on cays of the Swain Reefs, Great Barrier Reef, Australia. Journal of Biogeography, 17(1): 5-17. https://doi.org/10.2307/2845183

Smith, T.M., York, P.H., Broitman, B.R., Thiel, M., Hays, G.C., van Sebille, E., Putman, N.F., Macreadie, P.I. \& Sherman, C.D.H. 2018. Rare long-distance dispersal of a marine angiosperm across the Pacific Ocean. Global Ecology and Biogeography, 27(4): 487-496. https://doi.org/10.1111/geb.12713

Steinke, T.D. \& Ward, C.J. 2003. Use of plastic drift cards as indicators of possible dispersal of propagules of the mangrove Avicennia marina by ocean currents. African Journal of Marine Science, 25(1): 169-176. https://doi.org/10.2989/18142320309504007

Sunderland, T.C.H. \& Morakinyo, T. 2002. Nypa fruticans, a weed in West Africa. Palms, 46(3): 154-155. http://www.palms.org/palmsjournal/2002/vol46n3p154-155.pdf

Thiel, M \& Gutow, L. 2005. The ecology of rafting in the marine environment. 1. The floating substrata. Oceanography and Marine Biology - An Annual Review, 42: 181-264.

Thomas, D.C., Chatrou, L.W., Stull, G.W., Johnson, D.M., Harris, D.J., Thongpairoj, U-sa. \& Saunders, R.M.K. 2015. The historical origins of palaeotropical intercontinental disjunctions in the pantropical flowering plant family Annonaceae. Perspectives in Plant Ecology, Evolution and Systematics, 17: 116. http://dx.doi.org/10.1016/j.ppees.2014.11.001

Van der Burgt, X. (1997) African drift disseminules: 1. The Drifting Seed, 3(2): 5. http://www.seabean.com/newsletters/vol03-2.pdf

Van der Burgt, X. (1998) Drift seeds from the Netherlands and Gabon. The Drifting Seed, 4(1): 9-10. http://www.seabean.com/newsletters/vol04-1.pdf

Van Heel, W.A. 1974. Flowers and fruits in Flacourtiaceae II. The seeds of Pangium edule Reinw. Blumea - Biodiversity, Evolution and Biogeography of Plants, 22(1): 15-20. http://www.repository.naturalis.nl/record/524602

Van Sebille, E., van Leeuwen, P.J., Biastoch, A., Barron, C.N. \& de Ruijter, W.P.M. 2009. Lagrangian validation of numerical drifter trajectories using drifting buoys: application to the Agulhas system. Ocean Modelling, 29: 269-276. http://doi.org/10.1016/j.ocemod.2009.05.005

Vetter, J. 2000. Plant cyanogenic glycosides. Toxicon, 38(1): 11-36. https://doi.org/10.1016/S0041-0101(99)00128-2

Walter, A. \& Sam, C. 1996. Indigenous nut trees in Vanuatu: ethnobotany and variability. In: Evans, M.L., Bourke, R.M. \& Evans, B.R., eds. South Pacific Indigenous Nuts, 56-66. Proceedings of a Workshop held from 31 October to 4 
November 1994 at Le Lagon Resort, Port Vila, Vanuatu. ACIAR Proceedings No. 69.

Wurdack, K.J. \& Davis, C.C. 2009. Malpighiales phylogenetics: gaining ground on one of the most recalcitrant clades in the angiosperm tree of life. American Journal of Botany, 96(8): 1551-1570. http://doi.org/10.3732/ajb.0800207

Copyright retained by author(s). Published by BSBI under the terms of the Creative Commons Attribution 4.0 International Public License.

ISSN: $2632-4970$

https://doi.org/10.33928/bib.2019.01.219 